\title{
国指定文化財を除く全国の寺院本堂の建替えの実態 \\ 寺院本堂の長期利用に与える影響に関する研究 \\ RECONSTRUCTION STATE OF THE MAIN HALLS OF BUDDHIST TEMPLES \\ IN JAPAN THAT ARE NOT DESIGNATED AS CULTURAL PROPERTY \\ BY THE NATIONAL GOVERNMENT
}

A study on the impact on long-term use of the main halls of Buddhist temples

佐々木 健*, 勝又英明**

Takeshi SASAKI and Hideaki KATSUMATA

The following information was revealed about the reconstruction of main halls.

1. The main reasons for reconstruction of former main halls were deterioration, natural disasters, upgrading of functions and war.

2. The structure of the main hall was wooden in $80 \%$. The use of non-wooden structures peaked in the 1960 s, but wooden structures have again increased since the 1980 s nationwide.

3. Reconstruction of main halls could be categorized into those attributable to deterioration, disaster, upgrading functions and no reconstruction.

4. Passing down over many generations and placing importance on tradition will be a guideline for reconstructing the main hall.

Keywords : Temple, Main Hall, Traditional Wooden Structure, Non-wooden Structure, Reconstruction 封完，本堂，伝統木造，非木造，建替え

1. はじめに

\section{1 研究の背景と目的}

わが国には創立の古い寺院が数多く存在する。約 76,000 カ寺注 1) あると言われる伽藍の中でも本堂は中心的な建物であり, その多く は木造建築として, 代々の住職や檀信徒の協力, 堂宮大工等の工匠の 技術により継承されてきた。良い物を造り,長く大切に使う慣習は日 本人の育んだ文化の表れとも言え, 日本の伝統的な建築を代表する 寺院本堂は地域の景観資源ともなっている。本堂に求められる用途 注 2) が基本的に変わらないこと,腐朽した部材の交換が可能なこと も, 伝統的な木造本堂注3) の永続的な使用に繋がったと考えられる。 ところが,このように貴重な寺院本堂が, 災害や老朽化に伴い, 惜 しくも建替えられ, 地域から失われる事例はこれまで数多い。近代国 家形成の中で西欧から近代的な建築が導入され, 明治末には鉄筋コ ンクリート造 (以下, RC 造) 等の非木造注 4) の建築が建てられ注 5), 寺 院においても東本願寺函館別院注 6) が 1907 年の大火後に RC 造で再 建された。また, 1923 年の関東大震災による罹災寺院の復興注 7 ) や, 第二次世界大戦の本土空襲後の建替えで, 非木造本堂が建てられる ようになった。さらに, 建替えの際に, 国指定文化財以外の伝統的な 木造本堂にも建築基準法や消防法が適用注 8$)$ され,防火地域に指定さ
れた都心等には,古い木造の本堂を建替えられない寺院もある。ま た,50 年前と比べて人口が増える地域がある中で,高齢化や過疎化に よる限界集落の増加注9) は,農山村の寺院存続に影響を与えている。 このように,古い寺院本堂の環境は近代以降,様変わりしている。

一方, わが国では近年,歴史まちづくり法注 10) が制定され,城や神社 , 仏閣のような建造物が造り出す地域固有の風情や情緒等,都市や 農山漁村の良好な景観形成の重要性が再認識されている。

一度失われてからでは取り戻すことのできない歴史的景観と, そ れらを支える地域社会の存続は今後, ますます重要になると考える。

そこで, 本研究では,国指定の文化財を除く全国の寺院本堂を対象 として,現在の本堂に建替える前の本堂 (以下, 前本堂) と現在の本堂 (以下, 本堂) の実態,次に本堂を建替える際の構造選択とその理由等 から,寺院本堂の建替えに与える要因を明らかにすることとする。

\section{2 既往研究と本稿の位置づけ}

日本全国の寺院建築を対象とした研究には,破損が進み早急に包 括的な調査が必要であった未指定の文化財を対象とした近世社寺建 築調査注 ${ }^{11)}$ があり, 都道府県単位で選出された近世の社寺建築の遺構 を対象に,1977 年から 1990 年度に国庫補助事業として調査注 ${ }^{12)}$ が行 われた。また,横山は 1915 年から 1975 年に竣工した RC 造の寺院建

本論文は, 2007年度の東京都から2012年度の北海道・東北地方の寺院本堂を対象とした，年度毎の拙稿：参考文献22)〜29)を再構成したものである。

* 東京都市大学工学部建築学科 非常勤講師・MLA Lecturer, Dept. of Architecture, Faculty of Engineering, Tokyo City University, MLA

** 東京都市大学工学部建築学科 教授・博士 (工学) Prof., Dept. of Architecture, Faculty of Engineering, Tokyo City University, Dr. Eng. 
築注 13) の構造等の実態調査や曹洞宗寺院の計画に関する意識調査を 行った。千葉らは近代以降の東京の寺院注 ${ }^{14)}$ を関東大震災前, 震災後 〜戦前,戦後の 3 期に分け,寺院の集積と移転の実態を明らかにした。 また, 堀田らは秋田県の寺院本堂 ${ }^{\text {注 }}$ 15) の構造等に関する実態調查を行 った。村岡らは台東区の寺社建築の研究注 16) により,都市部における 伝統的な木造寺社建築を維持する上での防火的要件に関する問題を 指摘した。また, 中村は 19 世紀中期, 飛騨高山での建替えに伴う古材 の転用に関する研究注 17) を行った。さらに, 住宅の建替えは堤らの研 究注 18) や飯田らの研究注 19) で住宅の建替えの要因が示された。ところ が,近世社寺建築の調查では近世の社寺に限られ,また選定基準の偏 り等が指摘注 20) された。さらに,横山の研究では対象が非木造に限ら れ,千葉, 堀田,村岡, 中村の研究では対象地域が限定されていた。

このように,近世以前を含めた近世,近代,現代へと続く現存する日 本全国の寺院本堂の建替えの実態を明らかにする包括的な研究は, これまで実施されていない。この為, 失われつつある貴重な建物を維 持保全する為にも早期の調查が必要と考える。本研究では, 日本全国 の寺院本堂の建替えの実態を把握し,合わせて課題を明らかにする。

\section{2. 調査概要}

\section{1 調査対象}

本研究では, 日本全国の寺院を対象とした。初めに, 寺院のデータ ベースを作成した結果,総寺院数は 76, 849 注 21) となり,宗教年鑑に記 載された寺院数 77,421 注 22$)$ と比較して, 大きな差異はなかった。さ らに, 本研究の対象を伝統宗教注 23$)$ の寺院とし, 国指定の国宝・重要 文化財の本堂を除外した為, 調查対象は 74,584 寺院となった (表 1 )。 この中から無作為抽出法等により 17,574 寺院注 24) を選定し, 郵送に より,基本アンケート調査 (以下, 基本調查) 注 25 ) を実施した。

2007 年度の東京都から順次調查を実施し,2012 年度の北海道・東 北地方までの間に 2,661 件の有効回答 (有効回答率 $15.1 \%$ ) を得た。 なお, 宛所不明等の理由で返戻郵便の多い地方注 26) もあった。ま た, アンケートへの回答は基本的に住職へ依頼注 27) した。

\begin{tabular}{|c|c|c|c|c|c|c|}
\hline \multicolumn{7}{|c|}{ 表1 地方別調査対象寺院数と回答数 } \\
\hline & \multirow{2}{*}{$\begin{array}{l}\text { 基本調査 } \\
\text { 調査年度 }\end{array}$} & \multirow{2}{*}{ 総寺院 } & \multirow{2}{*}{ 調査対象 } & \multicolumn{3}{|c|}{ 基本調査 } \\
\hline & & & & 郵送寺院 & 返戻郵便 & 有効回答 \\
\hline 全国 & & 76,849件 & 74,584件 & 17,574件 & 1,079件 & 2,661 件(15\%) \\
\hline 北海道 & 2012年度 & 2,481 件 & 2,440 件 & 732件 & 56件 & 107 件 $(15 \%)$ \\
\hline 東北地方 & 2012年度 & 5,703 件 & 5,221 件 & 1,656 件 & 76件 & 325 件(20\%) \\
\hline 関東地方 & 2008年度 & 10,325件 & 10,216件 & 2,556 件 & 202件 & 356 件(14\%) \\
\hline 東京都 & 2007年度 & 2,974 件 & 2,748 件 & 1,851件 & 0件 & 418件(23\%) \\
\hline 中部地方 & 2010年度 & 22,067 件 & 21,836 件 & 4,363件 & 319件 & 597 件 $(14 \%)$ \\
\hline 近畿地方 & 2009年度 & 16,338件 & 15,854件 & 3,169 件 & 197件 & 519件(16\%) \\
\hline 中国地方 & 2011年度 & 6,511 件 & 6,286 件 & 1,255 件 & 85件 & 141件(11\%) \\
\hline 四国地方 & 2011年度 & 2,946 件 & 2,826 件 & 564件 & 46件 & 69 件 $(12 \%)$ \\
\hline 九州地方 & 2011年度 & 7,504件 & 7,157件 & 1,428件 & 98件 & 129件( $9 \%)$ \\
\hline
\end{tabular}

\section{2 調査方法}

アンケートによる基本調查の内容は, 創立等, 寺院の一般事項, 前 本堂の竣工年, 前本堂の建替え理由, 本堂の竣工年, 構造, 構造選択理 由, 次の本堂に選択する構造とその理由等とした。調査の主な項目を 表 2 に示寸。この他, 許可を得られた寺院にて, 本堂内部の調査やヒ アリング調查も適宜実施した。

\begin{tabular}{|c|c|l|}
\hline \multicolumn{2}{|c|}{ 表2 基本調査のアンケート項目 } \\
\hline \multicolumn{2}{|c|}{ 一般事項 } & 寺院名、住所、創立、移転年、移転理由、宗派、防火地域、用途地域 \\
\hline \multirow{2}{*}{ 実態調査 } & 前本堂 & 竣工年、構造、建替え理由 \\
\cline { 2 - 4 } & 本堂 & $\begin{array}{l}\text { 竣工年·(年代判別資料)、規模(面皘·階数)、構造·選択理由、構成 } \\
\text { 使用予定年数、次に選択する構造·選択理由 }\end{array}$ \\
\hline
\end{tabular}

\section{3 寺院の宗派}

本調査で回答を得た寺院の宗派別の比率 (表 3 ) は, 宗教年鑑に記 載された全国の宗派別寺院数注 ${ }^{28)}$ と比べ大きな差はない。なお, 宗 教年鑑には地方別に示した各宗派の寺院数の記載はないが, 地方別 でも概ね同様の結果が得られたと考えられる。

表 3 宗派別の寺院数(宗教年鑑,基本調査)

\begin{tabular}{|c|c|c|c|c|c|c|c|c|c|}
\hline & 天台系 & 真言系 & 浄土系 & 真宗系 & 禅系 & 日蓮系 & 奈良仏教系 & その他 & 総計 \\
\hline 宗教年鑑 & 4,522 & 12,627 & 8,898 & 20,752 & 20,842 & 6,955 & 272 & 16 & 74,884 \\
& $(6 \%)$ & $(17 \%)$ & $(12 \%)$ & $(28 \%)$ & $(28 \%)$ & $(9 \%)$ & $(0 \%)$ & $(0 \%)$ & $(100 \%)$ \\
\hline 基本調査 & 137 & 435 & 339 & 758 & 688 & 260 & 2 & 42 & 2,661 \\
& $(5 \%)$ & $(16 \%)$ & $(13 \%)$ & $(29 \%)$ & $(26 \%)$ & $(10 \%)$ & $(0 \%)$ & $(2 \%)$ & $(100 \%)$ \\
\hline
\end{tabular}

\section{3 . 寺院の創立と移転による建替え（日本全国）}

\section{1 寺院の創立}

寺院の時代別注 29) の創立(図 1 ) は, 寺請制度注 30) の始まった江戸よ りも,数多くの城郭や寺社が造営された鎌倉, 室町,桃山に多く, 6 割 以上を占め,創立の古い寺院が数多く現存していた。また,明治を創 立とする寺院も 102 件 ( $5 \%$ ) あり,地方別注 31$)$ では北海道は開拓時代 の布教の影響と考えられる(図 2 )。さらに,鹿児島県の場合は 7 寺院 全ての創立が明治以降であった。これは廃仏毀釈の影響注 32 と考え られる。なお,創立を把握していない 550 寺院は全体の $1 / 4$ であった。

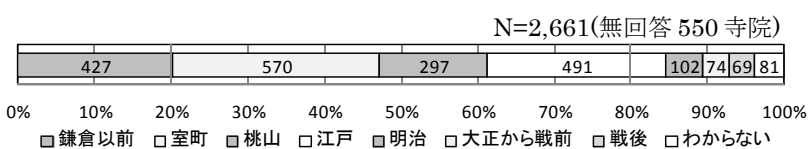

図 1 寺院の創立

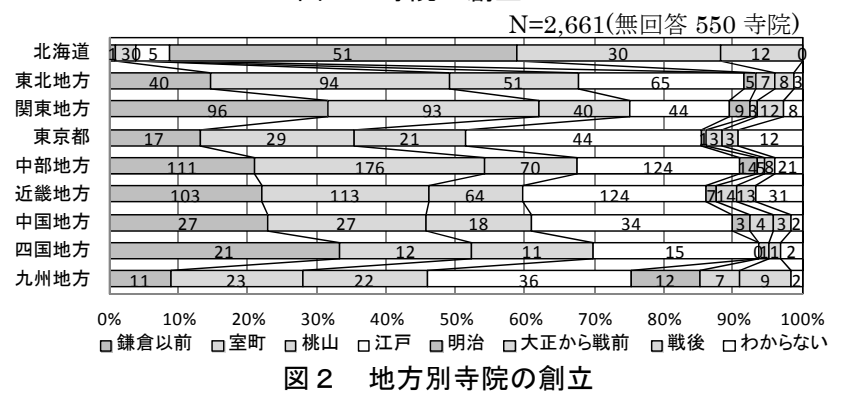

\section{2 寺院の移転と建替え}

寺院の移転では 3 割弱 (735 件) の回答を得た。移転理由としては 火災が多く, 都市計画, 藩 (諸国)の政策等, 自然災害, 土地の問題注 33 ), 兵火, 太平洋戦争, 関東大震災, 寺院の都合注 34) が続いた (図 3 )。そ の他には, 宗派の転向 15 件, 老朽化 12 件, 廃仏毀釈 11 件, 檀信徒を求 めて 11 件等であった。自然災害注 ${ }^{35)}$ には水害 21 件が多く, 地震, 台 風, 土砂崩れは何れも 3 件であった。火災の内訳は不明だが, 大火, 山火事, 放火, 失火, 災害等, 様々な要因が想定される。

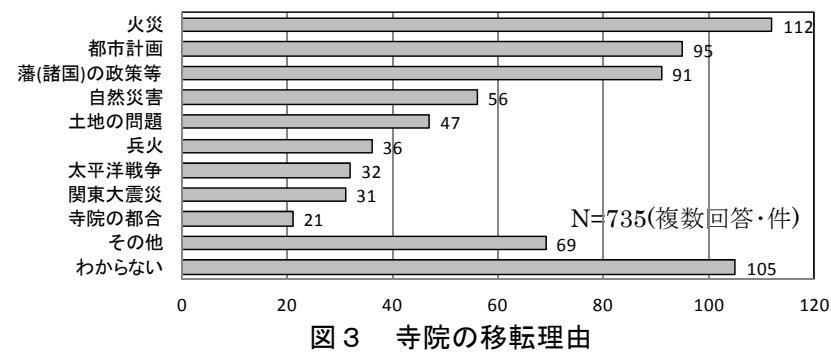

移転した時代注 36$)$ 別では, 桃山以前の 2 割に対して, 江戸は 4 割弱 と多い(図 4)。図 1 では, 江戸以前の創立は 8 割以上あり,移転は約 6 割となった。時代別の移転理由注 37 ) は, 江戸は火災で, 次に藩 (諸 
国)の政策が続いた (図 5 )。また, 江戸まで多くみられた, 藩の政策に よる寺院の移転は, 明治以降, 都市計画に変わっている。なお, 江戸の 藩の政策等には築城に伴う区画整理や造成等が, 明治以降の都市計 画には鉄道の開通, 道路拡幅, 堤防の拡張, 原爆後の都市計画等であ った。また, 火災による移転は江戸から徐々に減り, 大正からは関東 大震災に伴う移転注 38$)$, 戦後は太平洋戦争に伴う移転が多い。

$\mathrm{N}=578$ (無回答 55件)

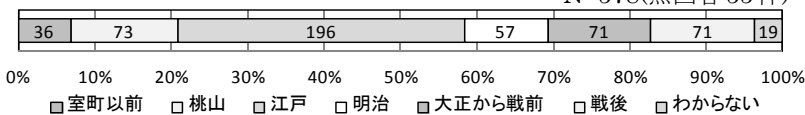

図 4 寺院の移転した時代

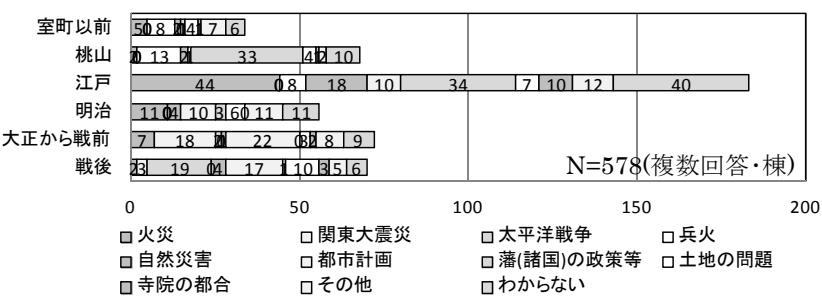

図 5 寺院の移転した時代と移転理由

地方別では, 東京は藩の政策等 42 件や, 関東大震災 30 件による移 転が多く,都市計画と太平洋戦争は 15 件, 火災は 13 件であった。ま た, 火災による移転はどの地方でも 1 ～ 2 割程度みられたが, 太平洋 戦争による移転は, 東京以外では近畿の 8 件, 中部の 5 件となった。 都市計画による移転は, 東京より東北 27 件, 中部 28 件, 四国 6 件にて 割合が高い。このように,時代毎の様々な理由による寺院の移転で, その都度,本堂の建替えや移築が行われたと考えられる。

\section{4. 前本堂の建替えの実態 (日本全国)}

前述のように, 前本堂とは現在の本堂を建替える前の本堂のこと を指す。したがって, 既に現存しない建物である為, 創立や移転等と は違い, 詳しい資料を持ち得ている寺院は限られると推測される。

本研究では, 基本調查の有効回答 2, 661 寺院の $51 \%$ となる 1,352 寺 院注 39) から, 前本堂の構造, 竣工年, 建替え理由への回答を得た。

そこで,ここでは, 前本堂の竣工した時代, 建替えた時代, 地域と, 各寺院の建替えた理由から, 本堂の建替えの要因を明らかにする。

\section{1 建替えられた前本堂の構造と竣エした時代}

前本堂の構造注 40) $は$, 木造 1, 051 棟, 非木造 19 棟, 混構造 2 棟と, 前本堂の多くは木造であった(図 6 )。前本堂の竣工した時代は古く, 室町以前は 34 棟。桃山と江戸前期を含めた 104 棟の中で 36 棟は, 戦後に建替えられていた (図 7 )。その一方で, 前本堂の戦後の竣工は 120 棟と多く, 戦後に竣工した前本堂が既に建替えられており, 長く 使われる本堂と短期間で建替えられる本堂があることを示す。

なお, 前本堂の竣工年は古いだけに, 現在の住職ではわからないと 回答した寺院は 457 寺院 $(38 \%)$ とやや多かった。

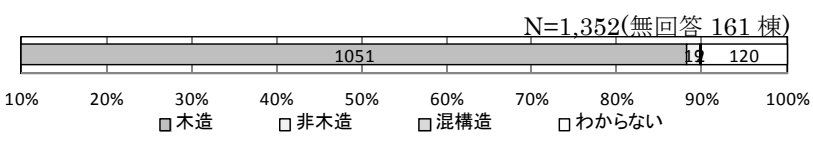
図 6 前本堂の構造

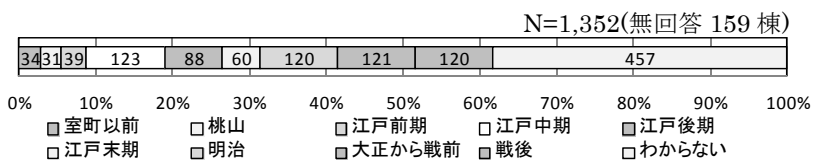

図 7 前本堂の竣工時代
前本堂の竣工した時代の地方別の特徴としては, 北海道や東京で は大正以降に建てられた比較的新しい前本堂が数多く建替えられて おり, 関東や九州がそれらに続いた（図 8)。一方, 中国地方では, 江 戸中期をはじめ, 江戸期に竣工した前本堂が数多く建替えられてお り, 明治以降は少ない。中部, 近畿, 四国では, 桃山以前に竣工した前 本堂の割合が 1 割強と多く建替えられていた。

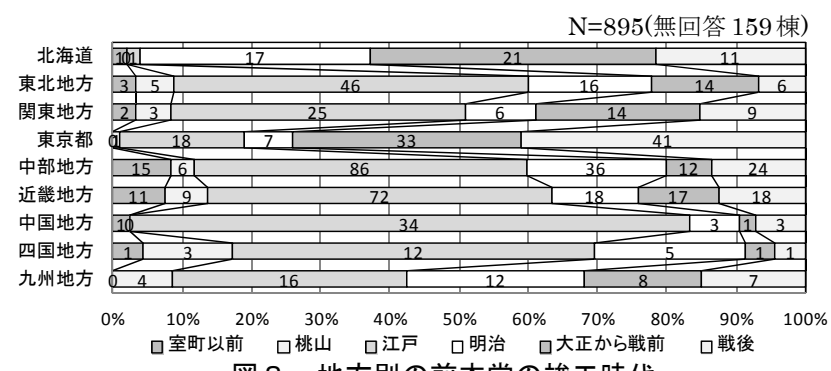
図 8 地方別の前本堂の竣工時代

\section{2 前本堂を建替えた理由}

前本堂は様々な理由で建替えられ,その理由は必ずしもひとつで はない。前本堂を建替えた主な理由は, 老朽化, 自然災害, 機能更新, 戦災等であった(図 9)。老朽化とは木造の場合は劣化や腐朽, 非木造 の場合は壁の亀裂等, 構造材への影響がある。仕上材では屋根材の劣 化や塗装の剥離等の老朽化もある。また, 主な自然災害注 ${ }^{41)}$ とは火 災, 地震, 台風, 水害であった(図 10)。次に多い, 機能更新注 42) とは空 調, 音響等の設備更新や, バリアフリーの対策等である。

次に, これらの理由を, 建替えを決定づけた直接の要因注 43) で区分 寸ると, 大きく自然災害と老朽化に分かれた (図 11)。なお, 複合要因 としては, 老朽化十機能更新 (65 件), 災害十老朽化 (33 件), 災害十老 朽化十機能更新 (15 件), 災害十機能更新 (12 件), 戦災+機能更新 (10 件) 等, 機能更新は災害, 戦災, 老朽化との複合事例が多い。また, 移転 を理由として前本堂を建替えた寺院は 23 件であった。

このように, 戦災と自然災害を災害と捉えれば, 本堂の建替えは大 きく「老朽化型」,「災害型」,「機能更新型」の 3 種類に分かれた。
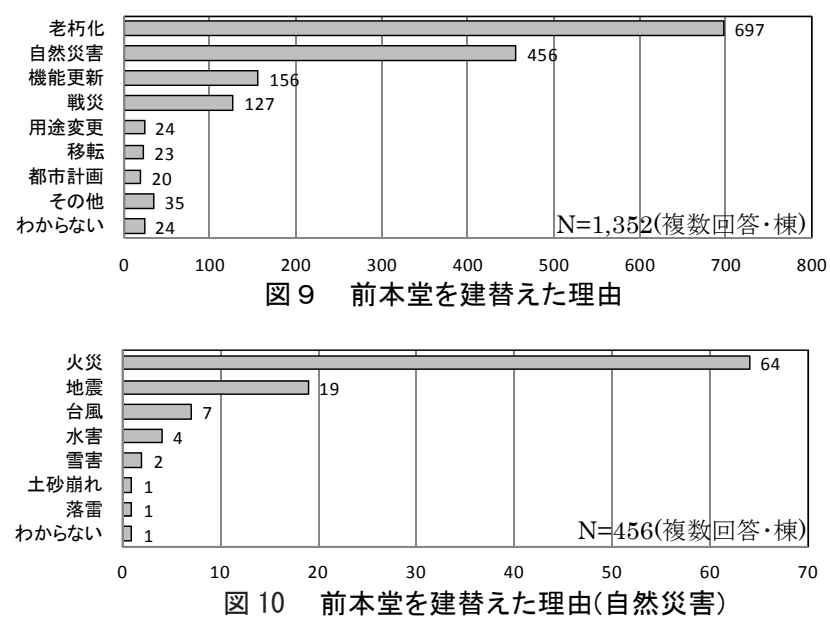

$\mathrm{N}=1,352$ (無回答 32 棟)

\begin{tabular}{|c|c|c|c|c|c|c|c|}
\hline & 456 & & 111 kदब & & 610 & & 0143 \\
\hline \multirow[t]{2}{*}{$0 \%$} & $10 \%$ & $30 \%$ & $50 \%$ & $60 \%$ & $70 \%$ & $90 \%$ & $100 \%$ \\
\hline & $\begin{array}{l}\text { 口自然災害 } \\
\text { 口老朽化 }\end{array}$ & $\begin{array}{l}\text { 口戦災 } \\
\text { 口機能更新 }\end{array}$ & $\begin{array}{l}\text { 口移転 } \\
\text { 口その他 }\end{array}$ & & $\begin{array}{l}\text { 布計画 } \\
\text { からない }\end{array}$ & 口用途変更 & \\
\hline
\end{tabular}

図 11 前本堂の建替え理由 


\section{3 前本堂の竣エした時代別の建替え理由}

前本堂の竣工した時代別の建替え理由は, 戦後に自然災害が減り, 機能更新の割合が増えるものの, 竣工した時代別では理由に違いは みられなかった(図 12)。次に, 前本堂を建替えた時代注 44) では, 全体 の約 6 割の 835 棟は戦後に建替えられていた(図 13)。前本堂の建替 えた理由を建替えた時代別にみると, 江戸以前から戦前は自然災害 が 5 割以上あったが、戦後は 2 割近くに減少した。また, 老朽化を理 由に建替えた寺院が, 戦後は 6 割程まで増加していた。戦後の復興と 高度成長に伴い都市や建物が近代化され, 次々と新しくなる中で, 修 繕されないまま戦時中を経過した寺院本堂の老朽化が顕在化された ことも戦後の老朽化による前本堂の建替えの一因と考えられる。
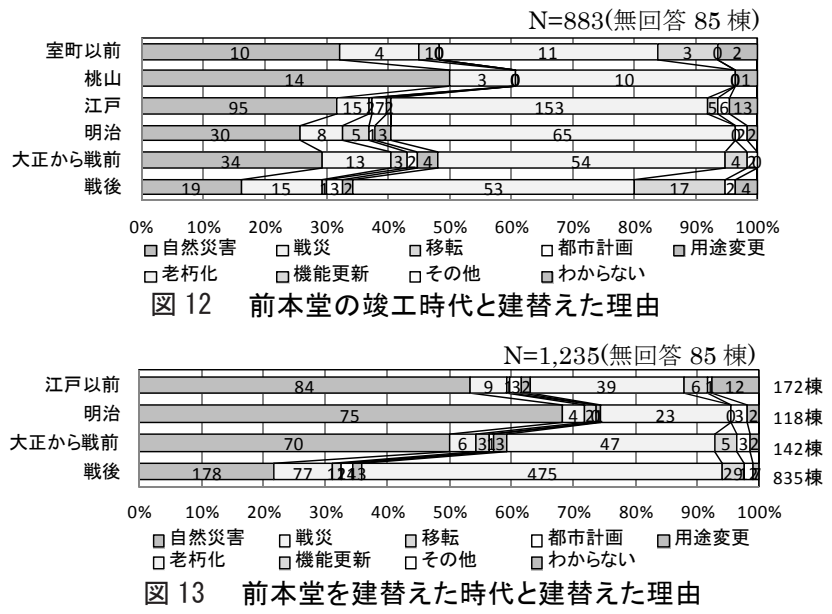

前本堂の竣工した時代は図 7 で示したように, 戦後に建てられた 新しい本堂から桃山以前まで,その時代の巾はかなり大きい。ここで は,古くから使われてきた前本堂が竣工した時代を江戸前期以前(江 戸前期,桃山,室町以前) とし, 比較的短期間で建替えられた前本堂の 䇋工した時代を戦後とした結果,それぞれ 36 棟と 119 棟となった(表 $4)$ 。また, 平均使用年数はそれぞれ 411.6 年と 33.6 年であった。

長い間, 使用してきた江戸前期以前の前本堂を建替えた理由は, 老 朽化 (72\%) に続き, 自然災害 (28\%) であった。一方, 短期間で前本堂を 建替えた理由も, 老朽化 (55\%) が最も多く, 機能更新 (34\%) が続いた。 割合 (\%)の多少はあるものの, 平均使用年数が 378 年違う建物を建替 えた理由が共に老朽化となった。前者は周期的に屋根を莫き替える 等, 維持修繥を繰り返しながら使われたものと推測されるが, 後者の 場合は例え 30 ４0 年でも修理をしなければ老朽化することを示し ている。また, 戦後に竣工した前本堂で老朽化と回答した 65 棟中 36 棟 $(55 \%)$ は, 物資も限られた戦後, 日の浅い 1955 年までに建てられて おり, 老朽化の一因となった可能性もある。一方, 江戸前期以前に竣 工した本堂の中には文化財的価值を有する本堂が含まれた可能性も あるが,これらも自然災害や老朽化等を理由に建替えられていた。

\begin{tabular}{|c|c|c|c|c|c|c|c|c|c|c|c|}
\hline \multicolumn{12}{|c|}{ 表4 江戸前期以前と戦後に建替えた前本堂の建替え理由 } \\
\hline & & \multirow{2}{*}{\begin{tabular}{|l} 
戦後に \\
本堂竣工
\end{tabular}} & \multicolumn{9}{|c|}{ 前本堂建替理由 (複数回答) } \\
\hline & & & 老朽化 & 自然災害 & 戦災 & 機能更新 & 用途変 & 司都市計画 & 移転 & その他 & $\begin{array}{c}\text { わから } \\
\text { ない }\end{array}$ \\
\hline \multirow{3}{*}{$\begin{array}{l}\text { 竣前 } \\
\text { 工本 } \\
\text { 年堂 }\end{array}$} & 江戸前 & & 2 & & 2 & & & & 1 & 0 & 0 \\
\hline & & $(100 \%)$ & $(72 \%)$ & $(28 \%)$ & $(6 \%)$ & $(8 \%)$ & $(0 \%)$ & $(0 \%)$ & $(3 \%)$ & $(0 \%)$ & $(0 \%)$ \\
\hline & 戦後 & $\begin{array}{c}119 \\
(100 \%)\end{array}$ & $\begin{array}{c}65 \\
(55 \%)\end{array}$ & $\begin{array}{c}19 \\
(16 \%)\end{array}$ & $\begin{array}{c}18 \\
(15 \%\end{array}$ & $\begin{array}{c}41 \\
(34 \%)\end{array}$ & $\begin{array}{c}2 \\
(2 \%)\end{array}$ & $\begin{array}{c}3 \\
(3 \%)\end{array}$ & $\begin{array}{c}1 \\
(1 \%)\end{array}$ & $\begin{array}{c}6 \\
(5 \%)\end{array}$ & $\begin{array}{c}4 \\
(3 \%)\end{array}$ \\
\hline
\end{tabular}

\section{5. 本堂への建替えの実態 (日本全国)}

創立が明治以前の寺院は 9 割あり, また平均して 100 年前後で前
本堂が建替えられていたことから,多くの寺院はこれまでに本堂を 何度か建替えたと推測される。前述の前本堂の実態では, 回答数が半 数程であったが, 実際には本堂の建替えは大半と考えられる。ここで は, 本堂の竣工した時代等から, 本堂の建替えの要因を明らかにする。

\section{1 本堂の構造と地方}

現在の本堂の構造は木造が 2, 098 棟 (80\%) となり, 前本堂 (図 6 ) と 同じく木造が多くを占めた。その一方で, 非木造は前本堂の約 20 倍 の 404 棟 $(15 \%)$ となり, 大半が前本堂を木造から非木造へ建替えた 寺院であった(図 14)。特に, 東京では非木造本堂の割合が他の地方 に比べて高く, 全体の 37\%を占めた。また, 大阪, 名古屋, 博多, 長崎, 広島, 仙台, 札幌等の地方都市にも比較的多くみられた (図 15)。混構 造本堂については特殊な事例であるためか, 棟数は少なく, 地方によ る違いもみられない。また, 木造本堂については, 東北や中国地方の ように, 9 割を占める地方もある一方, 新しい寺院の多い北海道では 7 割に留まる等, 本堂の構造別の割合は地方毎に特徵がみられた。

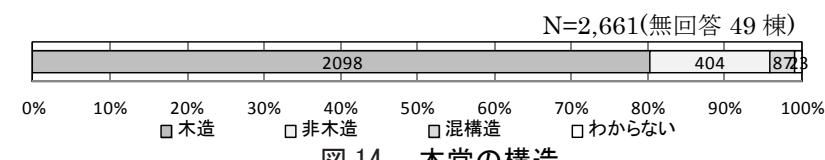

図 14 本堂の構造

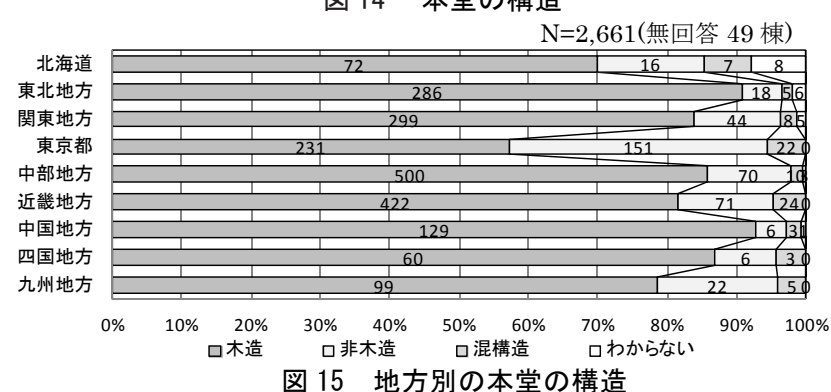

\section{2 地方別の防火指定地域等}

都市計画法注 45) にて, 防火地域と準防火地域が指定されている。 全国の寺院の指定注 46) の多くは無指定であったが, 東京では 84\%の寺 院が準防火または防火地域に指定され, 大阪, 京都, 名古屋, 川崎等の 一部にも防火地域に指定された寺院があった(図 16)。図 15 の非木 造本堂と防火や準防火地域指定との関係は特に東京でみられ, 建築 基準法や都市計画法等, 戦後に施行された法律により, 非木造で本堂 を建替えた寺院が東京には多数あると考えられる。

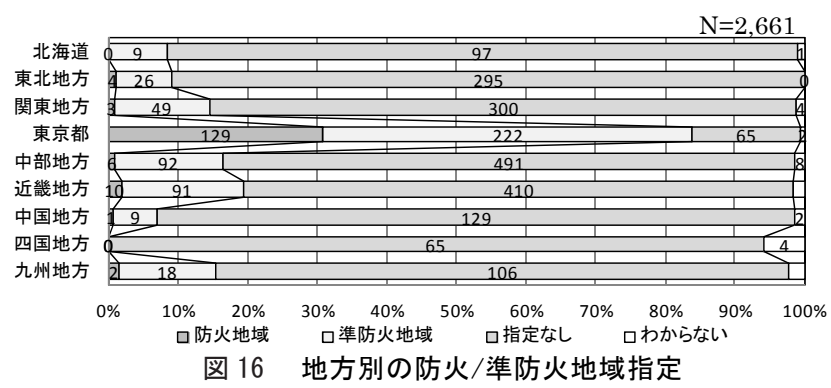

\section{3 本堂の竣エした時代}

本堂の竣工年については 2,486 棟 $(93 \%)$ と, 前本堂の約 2 倍の回答 を得た。前本堂と比べ, 戦後に竣工した本堂は約半数まで増え, 江戸 以前は $1 / 4$ にまで減っていた(図 17)。また, 現在の本堂ではあるが, 中には古い建物もある為, $7 \%$ 寺院では竣工年を把握していなかっ た。なお, 竣工年の判別資料注 47$)$ に, 棟札, 墨書, 寺史, 古文書, 過去 帳, 施工記録, 図面等の記録の他に, 伝承や記憶も含まれていた。 
$\mathrm{N}=2,661$ (無回答 174 棟)

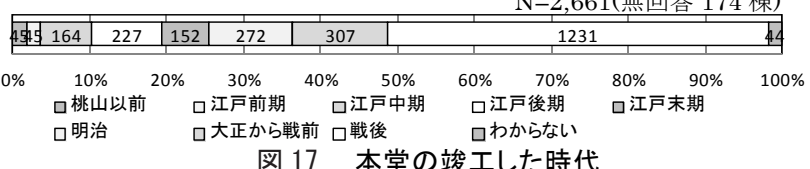

図 17 本堂の竣エした時代

図 15 に示したように, 非木造本堂も増えた為, 明治以降に竣工し た本堂を 10 年毎の構造種別で比較したところ, 1920 年代から非木造 の本堂が建てられていた(図 18)。前本堂では最も古い非木造の竣工 は 1945 年であったが, 前述のように, 現存する最も古い非木造の本 堂は東本願寺函館別院で, 1915 年に RC 造で建てられていた。数は少 ないが,この頃から徐々に非木造本堂が各地で見られる。その後, 60 年代と 70 年代が非木造本堂のピークとなり,この時期の木造本堂は 4 割まで減少した。しかし, 80 年代以降, 再び木造本堂が増加し, 全 国的には本堂の木造回帰を確認した。ただし, 地方別では大きく木造 一回帰する地方と緩やかな地方がある。中でも中部は 70 年代に $24 \%$ まで減った木造本堂が, 90 年代には 9 割まで回帰しており, 最も大き な変化がみられた。その一方, 東京では, 70 年代に 2 割まで減った木 造本堂が 80 年代に 5 割まで回帰したが, 緩やかであった。東京の場 合は, 5.2 で示した防火地域の指定が影響していると考えられる。

なお, 北海道は 60 年代に木造が 5 割まで減り 90 年代に 6 割まで回 帰, 東北は 60 年代に木造が 6 割まで減り 90 年代に 9 割まで回帰, 関 東 6 県は 60 年代に木造が 5 割まで減り 90 年代に 8 割まで回帰, 近畿 は 60 年代に木造が 3 割まで減り 90 年代に 6 割まで回帰する等注 48 , 全国的に本堂の木造回帰を確認したが, 非木造の普及と木造回帰の 時期と傾向は地方により異なる。なお, 混構造の本堂は少ない が, 1940 年代から建てられ, 非木造本堂と同じく減る傾向にある。

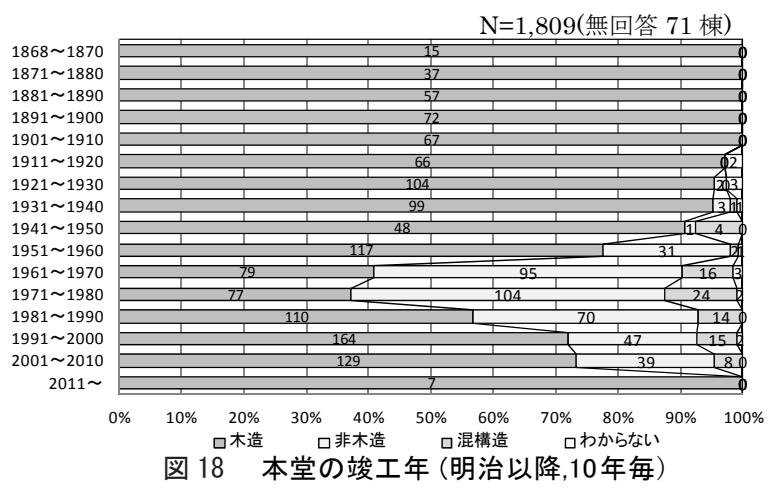

\section{4 本堂の構造と前本堂を建替えた理由}

前述のように, 戦後に普及した非木造本堂は減る傾向にあるが, 本 堂の構造を選択する上で, 前本堂を建替えた理由が影響を与えた可 能性が考えられる。前本堂を非木造で建替えた理由は, 戦災の割合が 高く, 非木造への建替えの要因になったと言える(図 19)。また, 戦災 で焼失した木造本堂が多いことも, 耐火性を期待した寺院が本堂の 建替えの際に, 非木造を選択したと考えられる。一方, 震災や台風等 の自然災害を理由に本堂を木造で建替えた割合が高いことから, 而付 震性等に対する木造本堂の信頼は高いと言える。なお, 老朽化や機能 更新は本堂建替えの際の構造選択との関連はみられなかった。

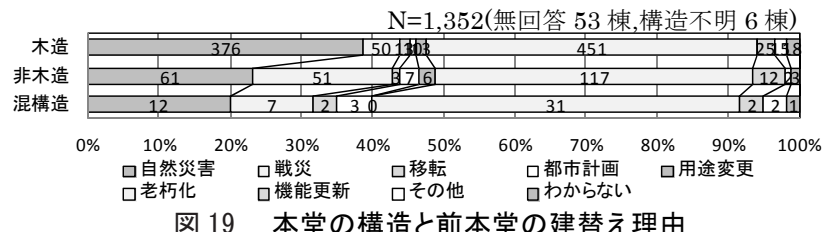

図 19 本堂の構造と前本堂の建替え理由
次に, 前本堂を建替える際に, 本堂の構造を変える寺院の, 構造別 の傾向を確認したところ, 多くは木造 $\rightarrow$ 造で全体の 7 割であった。 また,戦災は木造 $\rightarrow$ 非木造で最も多くなり, 前述を裏付ける結果とな った。この, 木造 $\rightarrow$ 非木造の本堂の 17\% (37 棟) は防火地域, 35\% (77 棟) は準防火地域, 48\% (107 棟) は無指定であり, 防火地域以外でも非木 造で, 多くの本堂が建替えられていた。機能更新は非木造 $\rightarrow$ 非木造の 寺院で多い。この非木造 $\rightarrow$ 非木造の 9 棟中 1 棟だけが防火地域であ り,機能更新の 3 棟は 2 階建以上 ( 2 階, 4 階, 7 階)で建替えられてい た。さらに,非木造 $\rightarrow$ 造では老朽化が多く, 非木造の耐用性一の懸 念から木造が見直されている面も伺える。この非木造 $\rightarrow$ 木造の 9 棟 中 1 棟注 49) は防火地域にあり, 3 棟は準防火地域, 5 棟は無指定であ った(図 20)。このように, 法的制約がなければ木造本堂に回帰する 寺院は今後も増えるものと推測される。

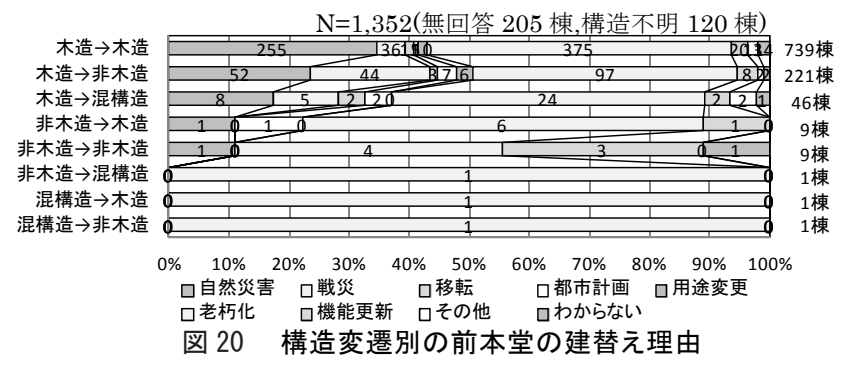

\section{5 本堂建替えでの構造選択の理由}

本堂が木造で建てられていた明治時代までは, 本堂の建替えにあ たり構造を選択する必要はなかった。しかし, 法的な制約等, 様々な 背景から木造以外の本堂が 2 割を占める現在は, 一般の建築物と同 様に, 本堂の建替えにあたり, 構造を選択寸る必要がある。主な本堂 の構造選択理由には, 寺院の伝統, 建物の永続性, 予算の制約, 素材感, 耐震性, 耐火性等が挙げられた (図 21)。構造別では, 木造本堂は寺院 の伝統, 素材感, 永続性といった伝統的な寺院の継承と木造ならでは の素材感が重視されていた。一方, 非木造本堂は, 耐火性, 予算の制約, 防火地域指定による制約等, 構造特性を反映した耐火や防火との関 係が強い。さらに, 混構造本堂は耐火, 予算等, 非木造と同様の傾向が みられるが, 寺院の伝統や素材感は木造と類似している(表 5 )。この ことから, 混構造本堂には, 木造の弱点である耐火性を確保しつつ, 寺院の伝統と素材感を実現された建物もあると推測される。なお, 木造本堂には古い建物も多い為, 構造選択の理由をわからないと回 答した寺院も $23 \%$ 程と比較的多くなった。

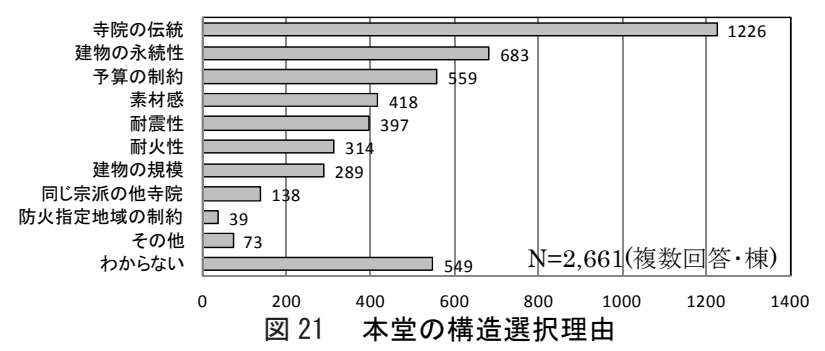

表5 本堂の構造と構造選択理由

\begin{tabular}{|c|c|c|c|c|c|c|c|c|c|c|c|c|c|}
\hline \multirow{2}{*}{\multicolumn{2}{|c|}{$\begin{array}{c}\text { 構造わから } \\
\text { ない } 23 \text { 棟) } \\
\end{array}$}} & & \multicolumn{11}{|c|}{ 構造選択理由(複数回答) } \\
\hline & & & $\begin{array}{l}\text { 寺院の } \\
\text { 沄統 }\end{array}$ & 素材感 & $\begin{array}{l}\text { 耐火 } \\
\text { 性能 }\end{array}$ & $\begin{array}{l}\text { 耐震 } \\
\text { 性能 }\end{array}$ & & \begin{tabular}{|c|} 
予算の \\
制約
\end{tabular} & \begin{tabular}{|c|} 
建物の \\
規模
\end{tabular} & \begin{tabular}{|l|} 
同宗派 \\
他寺院
\end{tabular} & $\begin{array}{l}\text { 防火指定 } \\
\text { 地域制約 }\end{array}$ & その他 & \begin{tabular}{|l} 
わから \\
ない
\end{tabular} \\
\hline & & 計 & 1,226 & 41 & 314 & 397 & & 559 & 289 & 138 & 39 & 73 & 549 \\
\hline & 木造 & & & & & & & & & & & $\begin{array}{c}51 \\
(2 \%)\end{array}$ & \\
\hline & 混構造 & & & $\begin{array}{c}14 \\
(16 \%) \\
\end{array}$ & & \begin{tabular}{|c|c}
18 \\
$(21 \%)$ \\
\end{tabular} & & & $\begin{array}{c}14 \\
(16 \%) \\
\end{array}$ & $\begin{array}{c}7 \\
(8 \%) \\
\end{array}$ & $\begin{array}{c}3 \\
(3 \%) \\
\end{array}$ & $\begin{array}{c}2 \\
(2 \%) \\
\end{array}$ & \begin{tabular}{|c|}
5 \\
$(6 \%)$ \\
\end{tabular} \\
\hline & & & & & & & & & $(16 \%)$ & & $\begin{array}{c}27 \\
(7 \%)\end{array}$ & $\begin{array}{c}20 \\
(5 \%)\end{array}$ & $\begin{array}{c}42 \\
(10 \%)\end{array}$ \\
\hline
\end{tabular}




\section{6 . 本堂への建替えの実態 (日本全国/東京)}

都市化の進んだ東京では本堂の建替えに, 戦後施行された法律の 影響がある。そこで, 全国の防火等指定地域と東京の用途地域指定注 50) 別の構造比率から, 建替えの要因を明らかにする。

\section{1 防火等指定地域と本堂の建替え（日本全国）}

創立は古く, しかも近年の移転は限られることから,多くの寺院は 土地に根ざした地域の歴史そのものと言える。東京も例外ではない が, 他の地方よりも都市化の影響を強く受け, 戦後に防火地域や準防 火地域の指定を受けた寺院の割合が高い(図 16)。文化財指定を受け ない限り, 防火等指定地域の有無は本堂の建替えの際の構造選択に も影響を与えると考えられる。防火地域に指定された寺院の木造本 堂は, 既に 3 割近くにまで減少していた(図 22)。このことは, 前本堂 までは元々木造で建てられていた多くの本堂が, 非木造等で建替え られたことを示寸。準防火地域で 6 割, 指定なしは 8 割が木造本堂で あることから, 防火地域の指定の影響が顕著に現れた結果と言える。

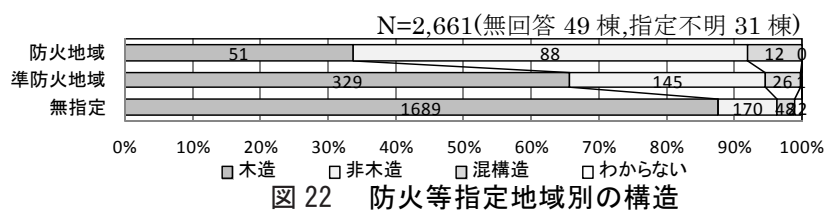

\section{2 用途地域と本堂の建替え (東京)}

防火地域の指定と同様に, 用途地域の指定も本堂の建替えの際の 構造選択に影響を与え, さらに寺院の周辺環境にも変化をもたらす と推測される。東京の寺院本堂は, 住居系よりも商業系や工業系に おいて非木造や混構造の割合が高く, 高い容積率に緩和注 ${ }^{51)}$ された 近隣の状況に追随した高層化や様々な用途を複合した本堂注 52) もみ られた(図 23)。一方, これらの地域にも木造の本堂が残されている。 防火地域では, 伝統的な木造による本堂は建てられない為, 部分的な 修理を繰り返すことで本堂を維持する寺院もみられた。

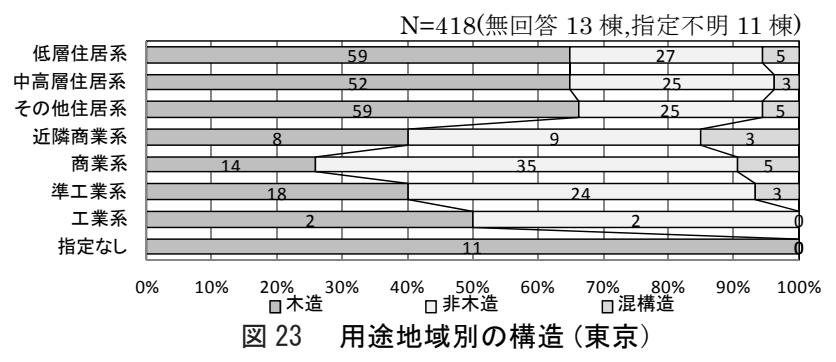

\section{7. 本堂の今後の建替え（日本全国）}

今後, 本堂を建替えるに当たり, 選択寸る構造とその理由, 本堂の 構造との関係から, 本堂の建替えの要因と課題を明らかにする。

\section{1 本堂の今後の建替えで選択する構造等}

「次の本堂に建替える際の構造」として, 木造, 非木造, 混構造の他 に, 現在の本堂を修理や補強を施してできる限り長く使用するとの 選択肢を含めた複数回答とした。したがって, 大きく 3 種類の回答, A. 現在と同じ構造, B. 現在と別の構造, C. 修理して使用に分けるこ とができる。A. を選択した寺院は現在の本堂が木造の寺院で $63 \%$ と， 非木造や混構造の 2 倍程度となった。次に, B. を選択した寺院は, 現 在木造では, 次に非木造よりも混構造と回答した割合が高い。また， 現在混構造では, 次に木造を選択した寺院が混構造の 2 倍以上とな った。現在, 非木造では僅かではあるが, 非木造より木造が上回った。
このように, A. 現在と同じ構造だけでなく, B. 現在と別の構造への建 替えにおいても, 木造の増加が伺えた。また, C. を選択した寺院は現 在木造の寺院で僅かではあるが他の構造より高い割合であった(表 6 )。なお, C. だけを選択した本堂のこれまでの平均使用年数は, 木造 110.4 年, 非木造 34.1 年, 混構造 34.0 年となり, 非木造や混構造の場 合は築浅の影響も考えられる。修理を繰り返しながら 100 年, 200 年 と使用し続ける行為は, 伝統的な木造建築元来の特長であり, 劣化や 腐朽した部材の部分的な取り替え, 柱の建て起こしや楔の締め直し 等の伝統的な技法を,一部の寺院では継承されていると考えられる。

一方, 非木造本堂の場合は今後, 修理事例を積み重礼ることも期待 される。このように, 建替えではなく, 現在の本堂を修理や補強を施 して,できる限り長く使用する寺院は，「非建替え型」と言える。

\begin{tabular}{|c|c|c|c|c|c|c|c|c|c|}
\hline \multicolumn{10}{|c|}{ 表 6 本堂の構造と次に選択する構造 } \\
\hline \multirow{2}{*}{\multicolumn{2}{|c|}{ （構造わからない23棟） }} & & \multicolumn{7}{|c|}{ 次に選択する構造(複数回答) } \\
\hline & & & 木造 & 混構造 & 非木造 & 修理し & 乙使用 & その他 & わからない \\
\hline & & 計 & 1,514 & 147 & 205 & & 68 & 55 & 216 \\
\hline \multirow{3}{*}{$\begin{array}{l}\text { 現 } \\
\text { 在 } \\
\text { の } \\
\text { 構 } \\
\text { 造 }\end{array}$} & 木造 & $\begin{array}{l}2,098 \\
(100 \%) \\
\end{array}$ & $\mathrm{A}_{(63 \%)}^{1,330}$ & $\begin{array}{lr}\mathrm{B} & 95 \\
(5 \%) \\
\end{array}$ & 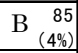 & $\mathrm{C}$ & $\begin{array}{r}629 \\
(30 \%) \\
\end{array}$ & \begin{tabular}{|c|}
43 \\
$(2 \%)$ \\
\end{tabular} & $\begin{array}{l}149 \\
(7 \%) \\
\end{array}$ \\
\hline & 混構造 & $\begin{array}{c}87 \\
(100 \%)\end{array}$ & B $\begin{array}{r}34 \\
(39 \%)\end{array}$ & $\begin{array}{l}\mathrm{A}_{(18 \%)} \\
\end{array}$ & 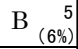 & $\mathrm{C}$ & $\begin{array}{r}18 \\
(21 \%) \\
\end{array}$ & $\begin{array}{c}3 \\
(3 \%)\end{array}$ & 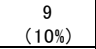 \\
\hline & 非木造 & $\begin{array}{c}404 \\
(100 \%)\end{array}$ & $\begin{array}{l}{ }^{1} 119 \\
(29 \%)\end{array}$ & B $\begin{array}{r}34 \\
(8 \%)\end{array}$ & $\mathrm{A}_{(27 \%)}^{111}$ & $\mathrm{C}$ & $\begin{array}{r}103 \\
(25 \%) \\
\end{array}$ & $\begin{array}{c}9 \\
(2 \%)\end{array}$ & $\begin{array}{c}49 \\
(12 \%)\end{array}$ \\
\hline
\end{tabular}

\section{2 本堂の今後の建替えの選択理由}

「次の本堂に建替える際の構造選択の理由」は多い順に, 世代を超 えて永く受け継ぎたい, 伝統を大切にしたい, 予算の制約, お寺の誇 り, 安心感, 檀信徒の希望, 維持修繥の負担軽減, 最新技術, 防火地域

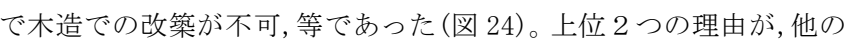
項目の 3 倍以上を占めた。これらの理由は, 構造選択だけでなく,様 式を含めた本堂を建替える際の今後の指針になるものと考えられる。

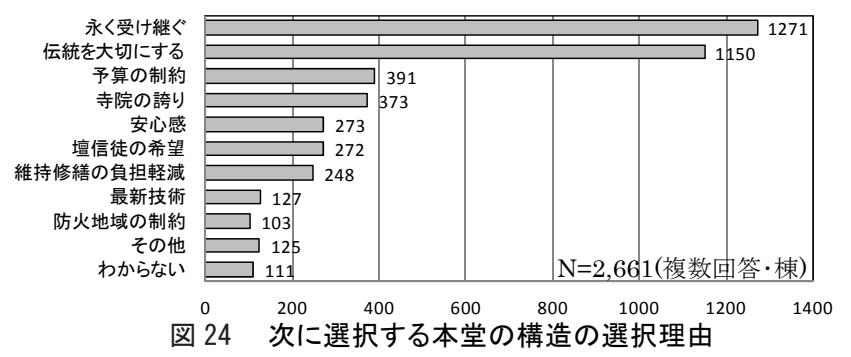

\section{3 本堂の今後の建替えで選択する構造等とその理由}

「次の本堂に建替える際の構造選択理由」は, (現在) 木造 $\rightarrow$ (次) 木造だけでなく, 非木造 $\rightarrow$ 造の寺院でも, 永く受け継ぐと伝統を大 切の割合が高い。一方, 非木造 $\rightarrow$ 非木造又は, 非木造 一修理の寺院は, 防火地域, 永く受け継ぐと, 予算の制約の割合が高い。また, 木造でも 非木造でも, 修理を選ぶ場合は予算の制約が高い割合を示した。しか し, 非木造 $\rightarrow$ 非木造では, 最新技術, 防火地域の割合が高い一方, 伝統 を大切にする割合は低かった (表 7 )。このように, 寺院として今後の 本堂に求める構造選択理由により,選ばれる構造等も多様となった。

\section{表7 本堂から次期本堂への構造と次期本堂の構造選択理由}

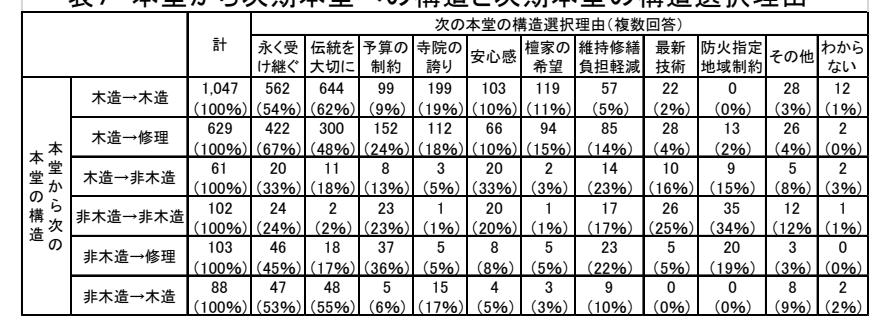




\section{8.まとめ}

国の文化財指定を受けない寺院本堂の建替えの実態について,下 記のことが明らかになった。

（1）寺院の創立と移転による建替え（日本全国）

寺院の創立は桃山以前が 6 割以上となり, 全国的には古い寺院が 多い中, 北海道や九州には明治以降の比較的新しい寺院も多かった。 また, 寺院の移転は江戸時代に多く, 移転理由は火災, 都市計画, 藩の 政策が多く,移転の結果, 本堂の建替え等が行われたと考えられる。

（2）前本堂の建替え（日本全国）

前本堂の約 6 割は戦後に建替えられ, 自然災害を理由とした前本 堂の建替えは戦後に減少し, 老朽化は戦後に増加していた。

前本堂を建替えた主な理由は, 老朽化, 自然災害, 機能更新, 戦災等 であり,また, 機能更新との複合要因の事例も多くみられた。

前本堂には長く使われた建物と短期間で建替えられた建物があり， 使用年数が大きく異なる建替えの主な理由が共に老朽化となった。 周期的に維持修繕をしなければ, 例え 30 年程度の使用でも老朽化し, 建替えに繋がる事例があることを示した。また, 前本堂の建替えを 「老朽化型」,「災害型」,「機能更新型」の 3 種類に分類した。

（3）本堂への建替え（日本全国）

本堂の構造は木造が 8 割であった。また, 前本堂と比較して本堂の 非木造は約 20 倍に増え, 大半が前本堂の木造からの建替えであった。 特に, 東京では非木造本堂の割合が高く, 全体の 37\%を占めた。

明治以降の本堂は, 60 年代と 70 年代が非木造のピークとなり,こ の時期の木造本堂は 4 割まで減少した。しかし, 80 年代以降は再び 木造本堂が増加し, 全国的には本堂の建替えで木造回帰を確認した。 戦災後に, 耐火性を期待して非木造で本堂を建替えたと思われる 寺院が多いが, 耐震性に対しては木造本堂の信頼は高いと言える。

本堂への建替えの多くは木造 $\rightarrow$ 木造で, 全体の 7 割を占め, 木造 $\rightarrow$ 非木造へ建替えた約 5 割は, 防火無指定地域に建てられていた。

本堂建替えの構造選択で, 木造では伝統的な寺院の継承と木造の 素材感, 非木造は構造特性を反映した耐火等との関係が重視された。

（4）本堂への建替え(東京)

東京は都市化の影響を強く受け, 防火地域に指定された寺院の木 造本堂は既に約 3 割まで減少し, 多くは非木造で建替えられていた。

（5）本堂の建替えの要件

本堂の建替えには「老朽化型」,「災害型」,「機能更新型」の 3 種類に加え, 伝統的な木造建築の特長である, 修理を繰り返し使用し 続ける「非建替え型」がある。

今後の本堂の建替えには, 世代を超えて永く受け継ぐ, 伝統を大切 にしたいとの理由と合わせて, 維持修繥の負担軽減, 最新技術, 安心 感, 防火地域指定, 予算の制約, お寺の誇り等も, 本堂の構造選択に影 響を与え, 今後, 本堂を建替える際の指針になるものと考える。

\section{謝辞}

調査にご協力いただいた住職の皆様に深く感謝致します。また, 貴重なアドバイスを下さった神戸芸術工科大学名誉教授, 伊藤延男 先生, 東京都市大学名誉教授, 故広瀬鎌二先生には大変お世話になり ました。なお, 本研究では東京都市大卒業生の梅澤研至氏, 伊藤美幸 氏, 鈴木万里恵氏, 中村苑子氏, 駒形祐輔氏, 市川貴大氏, 井田光哉氏, 伊藤大生氏他の協力を得ました。ここに, 記して感謝の意を表します。
また, 本研究では, (財) 鹿島学術振興財団, ならびに学術研究助成 金(基盤研究 $(C)$ ) による研究助成を受けております。

参考文献

1）文化庁編:宗教年鑑平成 23 年版, ぎょうせい, 2013.9

2）松村貞次郎: 新建築技術業書-8日本近代建築技術史, 彰国社, 1976.9

3) 桐敷真次郎: 明治の建築 (復刻版), 本の友社, 2001.7

4）藤岡洋保：日本の建築家が鉄筋ンコンクリート造に見た可能性, シリー ズ都市・建築・歴史 9 材料・生産の近代, 東京大学出版, 2005. 11

5）横山秀哉：コンクリート造の寺院建築, 彰国社, 1977. 3

6) 後藤治:都市の記憶を失う前に 建築保存待ったなし, 白揚社新書, 2008.4

7）財)農村開発企画委員会: 限界集落における集落機能の実態等に関する調 査報告書, 2007. 3

8）工藤圭章:近世社寺建築緊急調査の目的と現況, 建築歴史意匠部門研究協 議会, 建築雑誌 vol.98No. 1210, p. 131, 1983.8

9）北海道教育委員会他, 村上訒一編 : 北海道東北地方の近世社寺建築, 東洋 書林, 2003.7

10）栃木県教育委員会文化課 編: 近世社寺建築緊急調査報告書-栃木県建造 物調査報告書第 1 集, 栃木県教育委員会, 1978.3

11）奈良国立文化財研究所: 近世社寺建築の研究 第一号 第一回近世社寺 建築研究集会記録, 1988.7

12）圭室文雄: 近世社寺建築の研究 第二号 第一節 江戸幕府の宗教政策 -寺請制度を中心として-，奈良国立文化財研究所, 1990.3

13）千葉一輝, 戸沼幸市: 近代以降における寺院集積の変容について 東京の 寺院集積地区 (寺町) に関寸る研究 その 1 , 日本建築学会計画系論文集, 第 491 号, pp. 149-156, 1997. 1

14）堀田康介, 永井康雄, 他 : 秋田市・由利本庄市における近・現代寺院建築 について, 日本建築学会東北支部研究報告会, pp. 217-220, 2006. 6

15）村岡宏, 菅原進一:台東区における寺社建築とその防火管理に関する実 態調査都市部の伝統木造建築物の火災安全に関する研究, 日本建築学会 構造系論文集，第 539 号, pp. 175-182,2001.1

16）中村环巳:町協同施設の建替に伴う古材の処置-弘化 2 年の鍛冶橋およ び文政 11 年の高山町会所の建替普請について-, 日本建築学会計画系論 文集, 564 号, pp. 311-315, 2003.2

17）堤洋樹, 小松幸夫:居住者の改善行為から見た戸建住宅の建替え要因に 関する研究, 日本建築学会計画系論文集, 第 556 号,pp. 289-295, 2002.6

18）飯田雅史, 菊地弘明: 北海道における戸建注文住宅の建替えに関する実 態調査, 日本建築学会計画系論文集, 第 584 号, pp. 21-25, 2004. 10

19）これが日本のお寺神社だ!, http://www. otera. co.jp (参照 2007.6.10, 2008. 6. 3, 2009. 5. 20, 2010. 5. 14, 2011. 5. 19, 2012.4.26)

20) goo 多ソページ, http://townpage. goo. ne. jp/(参照 2011.6.23, 2012. 5. 31)

21）おてらなび, http://www. otera-navi. com/ (参照 2011.6.23, 2012. 5.31)

22）佐々木健, 勝又英明, 梅澤研至 : 東京都の寺院本堂 (構法)の実態:近代社 寺建築の変遷に関する研究 その 5 , 日本建築学会大会学術講演梗概集, E-1, pp. 1039〜 1040, 2008.9

23）伊藤美幸, 佐々木健, 勝又英明, 川合悠介：関東 6 県における寺院本堂の 計画と構法に関する調査, 近代社寺建築の変遷に関する研究 その 10 , 日本建築学会大会学術講演梗概集, E-1, pp. 1125～1126, 2009.8

24）鈴木万里恵, 佐々木健, 伊藤美幸, 水谷晋策, 勝又英明 : 近畿 2 府 4 県にお ける寺院本堂 (計画と構法) の実態, 近代社寺建築の変遷に関する研究 そ の 12 , 日本建築学会関東支部研究報告集, pp. 313 316, 2010.3

25）佐々木健, 鈴木万里恵, 勝又英明: 近代寺院本堂の防災, 関東地方・近畿地 方の実態と意識, 歴史都市防災シンポジウム‘10 歴史都市防災論集, Vol. 4 pp. $29 \sim 36,2010.7$

26）中村苑子, 佐々木健, 鈴木万里恵, 勝又英明: 寺院本堂の維持管理に関す る研究, 中部地方の寺院本堂を対象として, 日本建築学会大会学術講演梗 概集, E-1, pp. 1003 1004, 2011. 8

27）駒形祐輔, 佐々木健, 鈴木万里恵, 中村苑子, 林優介, 勝又英明 : 近代社寺 建築の変遷に関する研究, 中国・四国・九州地方の寺院本堂を対象として, 日本建築学会関東支部研究報告集, pp. 325 328，2011.3

28）佐々木健, 中村苑子, 勝又英明: 中部地方における寺院の防災対策の実態 調査, 東日本大震災前・後 (2010 年 12 月 ・ 2011 年 12 月) の調査を元に, 歴史都市防災ジポジウム゙12 歴史都市防災論文集, vol. 6, pp. 201〜206, 2012.7

29）佐々木健, 市川貴大, 勝又英明 : 近代社寺建築の変遷に関する研究, 北海 道と東北地方における寺院本堂の長期利用, 日本建築学会関東支部研究 報告書, pp. 265 268, 2012.3 
30）文化庁文化財部参事官, 国宝・重要文化財建造物目録, 2012.3

31）鹿児島県教育委員会:鹿児島県の近世社寺建築, 東洋書林, 1988.3

32）東京都市整備局の都市計画情報价ター祉提供サービス, 2009. 12

\section{注}

注 1 ) 参考文献 1) p. 33 による。

注 2 ) 本堂では, 主に, 葬儀や年忌法要の他, お彼岸, 法会, 施餓鬼等, 各宗派に

より様々な用途で利用されることが多い。

注 3 ) 伝統的木造本堂とは, 主として柱や梁等の構造の仕上に, 素木又は彩色 を施した木を用いた建物を指し, 基礎は石場建てには限定しない。

注 4 ) 非木造とは, 鉄筋コンクリート造 (RC 造), 鉄骨鉄筋コンクリート造 (以 後, SRC 造), 鉄骨造 (以後, S 造) を指す。

注 5 ) 明治時代等, 草創期の鉄筋コンクリート造の建築については, 参考文献 2）pp. 144～，参考文献 3）pp. 124～，参考文献 4)pp. 17～に詳しい。

注 6 ) 大谷派本願寺函館別院本堂は函館の大火で焼失後, 大正 4 (1915) 年に 再建。現存する最も古い $\mathrm{RC}$ 造本堂として, 2007 年に重要文化財に指定。

注 7 ) 参考文献 5) pp. 3〜 4 による。

注 8 ) 建築基準法や消防法の適用については参考文献 6)pp. 66〜 72 に詳しい。 また, 国指定文化財の適用除外については, 建築基準法第 3 条「文化財保護 法の規定によって国宝, 重要文化財等に指定された建物の場合は建築基準 法を適用しない。」による。なお, 建築基準法の一部改正(平成 5 年 6 月)に 伴い, 地方公共団体指定の文化財建造物にも条件付きで, 同法適用除外の措 置が受けられるようになった。

注 9 ) 参考文献 7)による。

注 10) 正式名称「地域における歴史的風致の維持及び向上に関する法律」は, 城や神社, 仏閣等の歴史上価值の高い建造物や歴史や伝統を反映し人々 の生活を良好な状態で維持・向上させる目的で平成 20 年 11 月 4 日に施行。

注 11) 参考文献 8) に「社寺建築の未指定文化財物件には, かなりの破損が進 んだものもみられ, 滅失するおそれのあるものもあって, 早急に総括的な調 査を実施する必要が認められていた。」と記載。

注 12) 参考文献 9)の p. 13〜14 に掲載された参考文献 10) 他, 全 64 冊の調査報 告書, ならびに, 参考文献 11) 他, 全 3 巻にて報告された。

注 13) 参考文献 5)による。

注 14) 参考文献 13)による。

注 15) 参考文献 14) 他による。

注 16) 参考文献 15)による。

注 17) 参考文献 16)による。

注 18) 参考文献 17)による。

注 19) 参考文献 18)による。

注 20) 参考文献 11) の p. 29 第三節 近世社寺建築緊急調査の総括にて, 細見啓 三は $2 つ の$ 問題 (i. 対象の基準が不統一で都道府県単位の数にばらつき, ii. 予備調査に挙らない建物が抜け落ちている)を指摘した。

注 21) 参考文献 19)により都道府県別リストを作成した結果, 福島, 徳島, 宮 崎, 沖縄, 北海道は参考文献 1) に記載された寺院数より一割以上少なかった。 そこで, 福島・徳島·宮崎では参考文献 20)を, 北海道・沖縄では参考文献 21) を併用した結果, 宗教年鑑の寺院数と同等以上となった。なお, 参考文献 19) は, 毎年 4 名程で $2 \sim 4$ 府県を担当の上, 記載日から約 1 ヶ月, 参考文献 20) と 21)による補完は約 1 週間費やし, 76, 849 寺院分のデータベースを作成した。 注 22) 参考文献 1)p. 34 には, 仏教系の単位宗教法人数 77, 421 と記載。

注 23 ) 伝統宗教とは, 新興宗教（宗教の開祖が 1900 年以後, およそ 100 年未満 の宗派とする）を除いた寺院と定義する。

注 24) 無作為抽出の抽出率 (\%) は, 調査した年度により, 20〜30\%と異なる (北 海道・東北 $30 \%$, 関東 $25 \%$, 中部・近畿・中国・四国・九州 $20 \%$ ) が, 初年 度の東京都は無作為抽出ではなく, 全寺院を対象として事前に電話調査を 実施し, 竣工年と構造を確認し, その後, 予定していた基本アンケート調査 の協力は不可と回答した寺院には, アンケートを送付しないこととした。

注 25) 基本調査とは, 地方別に全国の寺院へ行なう一律のアンケート調査で, これまでの研究成果は参考文献 22～29）等で発表した。

注 26) 返戻郵便は, 東京都では少なく, 過疎化の進んだ地域で比較的多くみら れた為,多くは住職が久員となり居住者不在の寺院と考えられる。

注 27) アンケートの回答者は, 住職 90\%, 副住職 4\%, 寺院関係者 3\%等となった。 また, 参考文献 1) pp. 50〜 53 には, 仏教系寺院として, (1) 文部科学大臣所轄 宗教法人 74,884 寺院, (2) 都道府県知事所轄宗教法人 53 寺院, (3) その他 186 寺院, 第 5 表 単立寺院 2,298 寺院の合計 77,421 寺院と記され,pp. 34 に記 載の仏教系の寺院数の内訳となる。なお, 単立寺院には本研究の対象外の新 興宗教の寺院が比較的多い為, 宗派別比較では (1) 文部科学大臣所轄宗教法
人 74,884 寺院を対象とした。

注 28）参考文献 1)pp. 66～79 に全国の宗教別寺院数が記載されている。

注 29) 参考文献 30) の建立年代区分表により,鎌倉は 1185 年〜 1332 年, 室町は 1333 年 1572 年, 桃山は 1573 年 1614 年, 江戸は前期 (1615 1660) ・ 中期 （1661～1750)・後期 (1751～1829)・末期 (1830～1867) , 明治は 1868 年〜 1911 年, 大正は 1912 年〜 1925 年, 昭和は 1926 年〜 1988 年, 平成は 1989 年〜とし た。なお, 戦前は〜1944 年, 戦後は 1945 年〜で区分した。

注 30) 参考文献 12) p. 6 に, 寺請制度は寛永十二年(1635)に施行されたと記載。 注 31) 地方別とは, 表 1 の調查年度毎に行った地方単位の集計で, 北から順に,

北海道, 東北, 関東 ( 6 県), 東京, 中部, 近畿, 中国, 四国, 九州 (沖縄含) となる。 注 32) 参考文献 31) に「薩摩藩では他藩と異なり, 寺請制度を採っていなかっ た為, 幕末・維新期における神仏分離に伴う廃仏毀釈の風潮が高まった」と 記載があるように, 江戸末期までに寺院のほとんどが廃寺となった。

注 33) 土地の問題とは, 狭い, 傾斜の山間から平地を求め等の回答であった。 注 34) 寺院の都合とは, 寺の政策, 代替地, 占想等の回答であった。

注 35) 自然災害の具体的な内訳 (水害, 地震等) は自由記入欄に記載された内容 であり, 25 件では自然災害にだけ回答され, 具体的な内容を把握していない

注 36) 寺院の移転年に関する設問は, 関東 6 県 (寺院の移転数 65 件) の調査 (2008 年度)では未実施の為, 母数は 735 から 670 に減っている。

注 37) 移転理由の複数回答のままではクロス集計を行えない為, 主となる理由 を1つ選ぶこととした。ここで, 主となる理由とは, 移転に至る直接の要因, 例えば, 災害と立地を選択した寺院の場合は, 災害として集計を行った。

注 38) 中には, 江戸前期に三河から築地に移転し, 関東大震災で本堂焼失時に ご本尊を守り, 再度, 世田谷へ移転し本堂を再建した寺院もあった。

注 39) 1,420 寺院にて前本堂の欄(竣工年, 構造, 建替え理由)に記載があった が, 46 寺院は前本堂と本堂の竣工年が同じ為, 本堂の竣工年を再度記入した と推測した。また, 22 寺院は前本堂の竣工年が本堂の竣工年後となってお り, 修理年を記載したと考え, これらを除いた 1,352 寺院を有効回答とした。 注 40) 基礎 (基壇等) が RC 造で, 柱, 梁, 壁, 屋根等の主構造が木造の場合は木造。 主構造が RC 造で内陣や須弥壇, 屋根下地等主構造以外が木造の場合は RC 造。 また, 混構造は RC 造(SRC 造) と鉄骨造等の異種構造の組み合わせとする。

注 41) 複数回答の母数は 456 あるが, 図 10 の選択肢は「その他」の自由記述 欄に記載された内容を分類したものであり,多くは「自然災害」が選択され ていた。なお, 3.2 でも記したように, 火災は明暦の大火, 山火事, 失火, 放火, 辻風, 地震等, 様々な要因を伴う為, ここでは自然災害に含めることとした。

注 42) 機能更新とは, 空調, 換気, 音響等の設備更新や, バリアフリーの対策, 用 途の複合化, 建物の複層化とする。

注 43) 前本堂の建替え理由は複数回答のままではクロス集計を行えない為, 建 替えを決定づけた要因の優先順位 (災害, 戦災, 移転, 都市計画, 用途変更, 老 朽化, 機能更新) を設け 1 つ選ぶこととした。ここで, 戦災は被害を受けてか ら着工までの社会的な安定が建替えまでの期間に影響を与えると判断し, 災害の後とした。また, 移転, 都市計画等も実施までに期間を要する為, 災害 等の後, 老朽化や機能更新は上記に継ぐ要因と判断し, 優先順位を決定した 注 44) 本堂の竣工年を前本堂の建替え年とした。戦災のような突発的な災害 の場合は, 戦災で焼失した時点で本堂が存在しないことも考えられ, 再建 の锥進に時間を要する場合もある為, 必ずしも本堂を建て替えた年まで 前本堂を使用していたとは限らない。但し,一般的には計画的に建替えが 行われることから,ここでは本堂の竣工年を前本堂の建替え年とした。

注 45) 都市計画法 9 条 20 (昭和 43 年 6 月 15 日) に, 防火地域, 準防火地域は, 市街地における火災の危険を防除するため定めると記載。

注 46) 不明箇所は, 自治体の HP と, 自治体への問い合わせで明らかにした。

注 47) 東京都 (2007 年度), 関東 6 県 (2008 年度), 近畿地方 (2009 年度)の調査で は, 竣工年の年代判別資料 (棟札, 墨書, 古文書, 過去帳, 図面等)の調查を未 実施のため,この地方では竣工年の根拠は確認できていない。回答には, 上 記の資料以外にも記憶や伝承も含まれたが, 先代の住職の時や大火の後等 のように,判断の基準が示されてもいる。

注 48) 中国は 60 年代に木造が 6 割まで減り 90 年代に $100 \%$ まで回帰, 四国は 60 年代に木造が $50 \%$ まで減り 90 年代に $100 \%$ まで回帰, 九州は 70 年代に木 造が $0 \%$ ま゙減り 90 年代に 6 割まで回帰していた。

注 49) 台東区竜泉の $\mathrm{S}$ 寺院で, 1968 年竣工の非木造を 1985 年に木造で建替。 注 50) 用途地域は, 参考文献 32) による。なお, 東京以外の地方では参考文献 31）と同様の用途地域の資料が公表されていない為, 調査はできなかった。 注 51) 東京都の防火地域における容積率は, 近隣商業地域で $300 \sim 400 \%$, 商業 地域で 400〜 700\%, 工業系で 200〜 400\%であった。

注 52) 本堂以外の用途は, 庫裏, 客殿, 書院, 会館, 納骨堂, 寺務所, 位牌壇等。 


\title{
RECONSTRUCTION STATE OF THE MAIN HALLS OF BUDDHIST TEMPLES \\ IN JAPAN THAT ARE NOT DESIGNATED AS CULTURAL PROPERTY \\ BY THE NATIONAL GOVERNMENT \\ A study on the impact on long-term use of the main halls of Buddhist temples
}

Takeshi SASAKI* and Hideaki KATSUMATA**

\author{
* Lecturer, Dept. of Architecture, Faculty of Engineering, Tokyo City University, MLA \\ ** Prof., Dept. of Architecture, Faculty of Engineering, Tokyo City University, Dr. Eng.
}

There are approximately 76,000 temples with a long dependent origination in Japan. In the complexes of temples, the main hall is the central structure, and many were carried on as wooden structures through the cooperation of generations of priests and followers, and the techniques of craftsmen such as temple carpenters. The custom of creating quality items and using them for a long time could also be called a manifestation of the culture created by the Japanese, and the main halls of temples representative of traditional Japanese architecture are also a landscape resource for the regions in which they are located. The fact that the basic application of a main hall is unchanged and the fact that rotting timber parts can be replaced are believed to be the factors that led to the permanent use of traditional wooden main halls.

However, there have been many cases such precious buildings unfortunately being reconstructed due to disasters and deterioration, and being lost from the region. Modern architecture was introduced from the West during the formation of the modern state, and many steel-reinforced concrete buildings were built at the end of the Meiji Period. Furthermore, main halls not made of wood began to be built in the recovery of temples affected by the Great Kanto Earthquake in 1923, and the reconstruction after the air raids of World War II. Furthermore, the environment surrounding old temple main halls has changed since modernization such as the application of Building Standards Act and the Fire Service Act to traditional wooden main halls not designated as cultural property by the national government during reconstruction.

The continuation of the historical landscape that cannot be recovered once it is lost, and the local community supported by it will become more and more important in the future.

This study covers the main halls of temples aims to unveil the factors affecting the reconstruction of the main halls of temples in Japan that are not designated as cultural property by the national government.

The following information was revealed about the reconstruction of main halls.

(1) Reconstruction of temples due to relocation

Many relocations of temples took place during the Edo Period, and the reason for relocation is fire, urban planning and domain policy in many cases, and it is believed that the main hall was reconstructed as a result of relocation.

(2) Reconstruction of former main halls

Approximately $60 \%$ of former main halls were reconstructed after the war.

The main reasons for reconstruction of former main halls were deterioration, natural disasters, upgrading of functions and war. Reconstruction of former main halls could be categorized into those attributable to deterioration, disaster and upgrading functions.

(3) Reconstruction of main halls

The structure of the main hall was wooden in $80 \%$ of all cases. The proportion of non-wooden structure is particularly high in Tokyo, accounting for $37 \%$ of the total. Since the Meiji Period, the use of non-wooden structures in main halls peaked in the 1960s, and the proportion of wooden main halls during this period decreased to $40 \%$. Wooden structures have again increased since the 1980s, and the return to wooden structures in reconstruction has been confirmed nationwide. In the selection of structures in the reconstruction of main halls, emphasis was placed on the continuation of traditional temples and the texture of wooden structures, and the relationship with fire resistance reflecting structural characteristics in non-wooden structures. Reconstruction of main halls can be categorized into "No reconstruction" that is Repairing and reinforcing the current main hall and using it as long as possible. 